\title{
XII. Experiments on the nature and properties of the Pietra fongaja, lapis fungifer
}

\section{P.A. Gadd}

To cite this article: P.A. Gadd (1799) XII. Experiments on the nature and properties of the Pietra fongaja, lapis fungifer, Philosophical Magazine Series 1, 5:19, 279-280, DOI: $10.1080 / 14786449908677153$

To link to this article: http://dx.doi.org/10.1080/14786449908677153

曲 Published online: 18 May 2009.

Submit your article to this journal $[\pi$

Џ Article views: 2

Q View related articles $\asymp$ 


\section{$[279]$}

XiI. Experiments on the Nature and Properties of the Pictra fongaja, Lapis fungifer*. By P. A. GADD †.

S which fometimes is ufed to denote the harder fort of ftones, 2s well as ftones of a certain genus; for example, Pietra bigia, obfidiana, nepbritica, \&c.; and this is the cafe with the fo called Pietra fongaja. I. I. Ferber may be confidered as the firf perfon who gave a defcription of it in his letters from Italy. He has remarked alfo that a kind of it is in common ufe in the houfes of Naples and Rome; and that he faw another kind in the poffeffion of M. Fabbroni, at Florence: the firft kind, which was found in the chalk-hills near Naples, confifted of white calcareous ttalactites, and a number of fmall roots of vegetables; the latter was a hardened turf, dug up in the neighbourhood of fome volcanic mountains.

A few years ago, M. Charles Spärre, chancellor of the academy, having been fo kind as to tranfmit to me a piece of pietra fongaja, which he had brought with him from Italy. I analyfed it, and found the refult as follows:-It burns in an open fire, and emits the fmell of putrid vegetables. When burnt in a ftrong fire, the greater part of it becomes darkgrey athes. A hundred parts of this hardened turf, loft about fifteen parts in weight. When fufed in a ftronger heat, it is converted into a black opaque flag, which, however, is difficult to be fufed. When a fmall part only of this earth is fufed with borax, the glafs acquires a dark-green colour. If a little water be poured over the calcined earth, the water exhibits traces of diffolved pot-anh, but the earth does not appear to have thereby fenfibly decreafed in weight. One hundred parts of the earth, previoufly calcined in a crucible, being analyfed, ivere found to cuntain about 45 or 46 of filiceous earth, 23 argil, 7 calcareous earth, 20 calx of iron, together with traces of magnefian earth and pot-alh.

When the pietra fongaja is kept in a cellar, and moiftened

* Muthroom ftone, or muthroom-bearing ftone.

+ From Tranfac. Rugal Acat. Sturkioim for 1797. 
with water, it produces a great many eatable mufhrooms, which in Italy are ferved up at the tables of the great as delicacies. It needs excite no wonder that mufhrooms fhould grow on the pietra fongaja, fince a multitude of fruitul muthroom feeds are intermixed in this foft ftalactites, as well as with the hardened turf found near volcanoes.

For the information of thofe who may be defirous of making mulhrooms continually grow up from the pictra fongaja, and of increafing the quantity, it may be neceffary to remark, that this effeet will be produced, if, according to the experiment of $\mathrm{M}$. Gleditfch, the muthroom-ftones kcpt in cellars be moiftened with water in which muthrooms have been wafhed *.

XIII. On the Volcanic Ifland tbrown up in the Neigbbourbood of Iceland. By Captain Von Löwñön, of tbe Danifb Navy + .

IN

$\mathrm{N}$ the fpring of the year 1783 , a volcanic illand, thrown up in the neighbourhood of Iceland, excited no little attention. According to the account of the fea-captain, who firft faw it, exactly at the time when it firft arofe, fmoke and flame feemed to rife from the fea, but no land or ifland was to be feen. It nceds excite no. wonder, therefore, that the obferver was thrown into the greateft confernation, as he fays himfelf, when he beheld the fea on fire! He and the whole crew therefore conchuded that the end of the world had arrived, and they all began to prepare themfelves for the awful moment: but, as they heard no trumpet, and as the fun thone in the firmament with his ufual brightnefs, after confidering what the phenomenon might be, they at laft concluded that Iceland had been fwallowed up by an earthquake; that this was a remainder of it; and that the flames arofe from Hecla, the well-known volcano of that inand. Full of this idea, they were juft on the point of re-

* Does no: this furnifh a hint to thofe who rear muitroms in garúns on beds of horfe-dung? EDir.

+ From Geograpbifice Ephemeriden, 1799. 